\title{
Germination traits of three weed species in Kosovo
}

\author{
Arben Mehmeti, Adem Demaj and Rainer Waldhardt
}

\begin{abstract}
Mehmeti, A., Demaj, A. and Waldhardt, R. 2010. Germination traits of three weed species in Kosovo. - Web Ecol. 10: 15-22.
\end{abstract}

\begin{abstract}
Amaranthus retroflexus, Echinochloa crus-galli and Datura stramonium are the most important weed species in Kosovo. They cause severe yield depression, contaminate fodder and negatively affect growth and reproduction of other weed species. To counteract these problems, specific strategies need to be developed. Such strategies should consider information on species germination traits. In this context, our study provides information on temperature requirements for germination. Seeds of $A$. retroflexus, E. crus-galli and $D$. stramonium were harvested in two sub-regions of Kosovo (western and eastern parts) differing in climate and land use. They were set for germination experiments in growth chambers at temperatures ranging from 3 to $35^{\circ} \mathrm{C}$ and under field conditions. In both experiments, the germination rate differed between species and provenances. In the growth chamber experiment, germination of all three species was negligible below $15^{\circ} \mathrm{C}$ and reached the highest rates between 24 and $30^{\circ} \mathrm{C}$. Seeds originating from the western part of Kosovo had higher germination rates and required a lower temperature for germination than seeds originating from the eastern part. In the field experiment, the time-dependent germination behaviour of D. stramonium differed between provenances. In general, germination started when soil temperature was above $18^{\circ} \mathrm{C}$ and continued as long as the soil was moist. The results are discussed in the context of the need to develop weed management strategies against these weeds in Kosovo.
\end{abstract}

A. Mehmeti (arben.mehmeti@umwelt.uni-giessen.de) and R. Waldhardt, Landscape Ecology and Landscape Planning, Justus-Liebig-Univ. Giessen, Heinrich-Buff-Ring 26-32, DE-35392 Giessen, Germany. - A. Demaj and AM, Plant Protection, Univ. of Prishtina, Bill Clinton p.n., 10000 Prishtina, Kosovo.

Crop yields (3.5 tonnes ha $\mathrm{h}^{-1}$ for wheat and 2.2 tonnes $\mathrm{ha}^{-1}$ for maize) of Kosovo, located in the centre of the Balkan Peninsula (southeast Europe), do not meet the food demands of the increasing population (Statistical Office of Kosovo 2008a, 2009). Among the multiple reasons for the insufficient productivity of agriculture (e.g. land fragmentation, lack of machinery), one is the predominance of three main weeds, Amaranthus retroflexus, Echinochloa crus-galli and Datura stramonium. These three species are both frequent at the regional scale and abundant at the plot scale (Mehmeti et al. 2009). Their competition with crops often leads to significant yield losses (Knežević et al. 1995, Bosnic and Swanton 1997, Cavero et al. 1999, Oljaća et al. 2006). Moreover, due to its high concentrations of alkaloids, D. stramonium may contaminate fodder, which is produced in large parts of Kosovo's fields.

The strong competitors $A$. retroflexus, $E$. crus-galli and $D$. stramonium may also have negative impacts on the populations of other, less competitive weed species. Further, chemical or mechanical control measures may endanger other rare plant species (cf. Mehmeti et al. 2009). To counteract the agronomic and ecological problems mainly caused by 3 problematic weed species, strategies should be implemented to reduce the level of infestation and, at the 
same time, allow for the establishment of species-rich weed communities. In this context, information on species characteristics, including germination traits, may be helpful to determine periods in the life cycle where weed control measures will be most effective (Ghorbani et al. 1999, Guo and Al-Khatib 2003, Sellers et al. 2003). In general, such information on the occurrence, morphology, and ecology of $A$. retroflexus, E. crus-galli and D. stramonium is available from many publications from different parts of the world: all three species are common weeds not only on the Balkan Peninsula (Stanković et al. 1996, Vrbničanin et al. 2004, 2006), but in many regions all over Europe and beyond (Malan et al. 1982, Siriwardana and Zimdahl 1984, Reisman-Berman et al. 1989, Saavedra et al. 1989, Bosnic and Swanton 1997, Bürki et al. 1997, Sellers et al. 2003, Martinkova et al. 2006, GBIF 2009), especially on high-fertility soils. All three species produce a high biomass and a high seed number per individual (Korsmo 1930, Nussbaum et al. 1985, Benvenuti et al. 1994, Bosnic and Swanton 1997, Norris et al. 2001, Sellers et al. 2003, Kovačević et al. 2004, Simončič and Leskošek 2005, Oljaća et al. 2006, Vrbničanin et al. 2006). Herbicide-resistant genotypes are widespread (Glauninger 1984, Solymosi and Kosyal 1985, Maun and Barrett 1986, Williams et al. 1995, Stanković et al. 1996, Janjić et al. 2003) and the long-lived seeds accumulate in the soil (Kozlowski 1972, Malan et al. 1982, Maun and Barrett 1986, Thompsson et al. 1997, Uremis and Uygur 2005). The seed germination behaviour of $A$. retroflexus, E. crus-galli and D. stramonium strongly depend on species-specific characteristics such as dormancy (Rahn et al. 1968, Barrett and Wilson 1983, Reisman-Berman et al. 1991, Martinkova and Honek 1995, Honek et al. 1999, Omami et al. 1999, Cristaudo et al 2007) and environmental factors (e.g. soil temperature, soil moisture, and light irradiation). Seeds of all three species germinate in spring provided the soil temperature exceeds $15^{\circ} \mathrm{C}$ (Vengris et al. 1966, Brod 1968, Baskin and Baskin 1977, Malan et al. 1982, Ghorbani et al. 1999, Guo and Al-Khatib 2003, Steckel et al. 2004), being potential competitors to maize and other summer crops (Maun and Barrett 1986, Cavero et al. 1999, Kovačević et al. 2004).

However, species characteristics may considerably differ between provenances (Keller and Kollmann 1999, Hamasha and Hensen 2009). Thus, information on species traits needs to be taken into consideration for the development of local control strategies. Unfortunately, research on species traits at the local level in Kosovo has not been conducted in recent years. Therefore, the aim of our study is to provide such data based on growth chamber and field experiments. The focus of our study is on temperature requirements for germination of $A$. retroflexus, $E$. crusgalli and $D$. stramonium. To this end, we compared germination rates of these species, testing the hypothesis that species-specific seed germination rates of $A$. retroflexus, $E$. crus-galli, and D. stramonium differ between provenances (western vs eastern parts of Kosovo).

\section{Material and methods}

\section{Study region, seed collection and preparation}

Kosovo (Fig. 1) covers an area of $10877 \mathrm{~km}^{2}$ in the centre of the Balkan Peninsula (southeast Europe). The elevation ranges from $265 \mathrm{~m}$ to $2656 \mathrm{~m}$ a.s.l., with about $80 \%$ of the entire area below $1000 \mathrm{~m}$ and dominated by agriculture on fertile and, to some extent, irrigated soils (mainly fluvisols, vertisols, cambisols, and regosols). In general, the climate is characterised by warm summers and cold winters, and air temperature may range from $-20^{\circ} \mathrm{C}$ to $35^{\circ} \mathrm{C}$. However, in the western part of Kosovo, the average air temperature $\left(11.0^{\circ} \mathrm{C}\right)$ and the annual rainfall are higher (about 780 $\mathrm{mm}$ ), and the frost-free period (up to 225 days) is longer than in the eastern part $\left(9.8^{\circ} \mathrm{C} ; 635 \mathrm{~mm} ; 170\right.$ to 220 days, respectively). About $14 \%$ of the entire country surface area is devoted to agriculture (Statistical Office of Kosovo 2008b). Wheat and maize are the most important crops. Pepper, onion and tomatoes are produced on less acreage (about $4000 \mathrm{ha}$ ) and are concentrated to the western part of the region. Pesticide use, including triazine herbicides, was common until about 1990. For economic reasons and due to a lack of supply, herbicide use has remained restricted to parts of the arable land in the last two decades (cf. Mehmeti et al. 2008, 2009).

In summer 2006, we harvested mature seeds of $A$. retroflexus, E. crus-galli and D. stramonium in two sub-regions

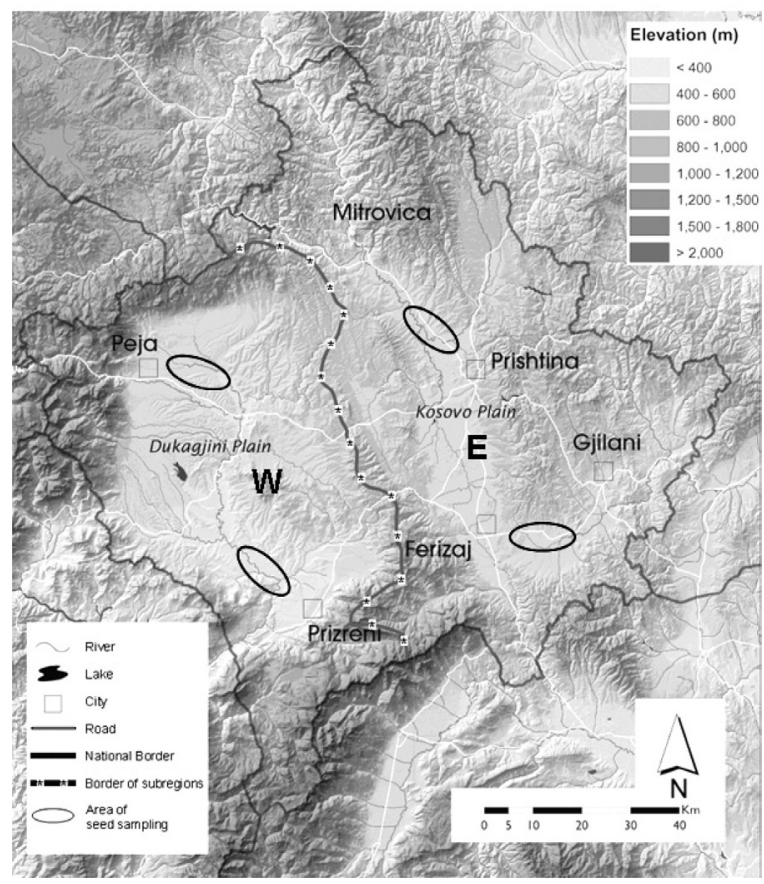

Figure 1. Areas of seed collection in two sub-regions W and E of Kosovo. 
of Kosovo (W = western part, $\mathrm{E}$ = eastern part) differing in climate and land use as outlined above. In each sub-region, seed collection concentrated on 10 randomly selected arable fields in two small areas. We collected about 20000 seeds per species in each sub-region and stored seeds as six pooled seed samples (3 species, 2 sub-regions) in a cool, dry and dark place.

To compare the quality of the seeds in the pooled samples, we measured the length and the width of 25 seeds per sample and calculated the mean. Moreover, we estimated the thousand-kernel weight (TKW) of each pooled seed sample using a CONTADOR seed counter. Finally, we tested 25 seeds of each pooled sample for seed viability with tetrazolium prior to the experiments.

\section{Germination experiment in growth chambers}

In autumn 2006, we conducted a seed germination experiment in growth chambers (RUMED type 3401) to test temperature-dependent germination rates of each of the six pooled seed samples for nine different treatments (constant temperature at $3,7,10,15,20,25,30$, and $35 \mathrm{C}$, and diurnally fluctuating $(8 / 16 \mathrm{~h})$ temperatures, $\left.5 / 15^{\circ} \mathrm{C}\right)$ as described in Otte (1996) and Hölzel and Otte (2004). We put 50 seeds of each seed sample on a double layer of filter paper in sterile Petri dishes. For six weeks, we incubated the seeds of five dishes per seed sample and treatment. The light regime was equal for all seed samples and treatments, with permanent lightning during the whole period. We watered all dishes regularly with distilled water to optimize moisture conditions. Germinated seeds were counted weekly and removed. Germination was defined as the emergence of the radicule.

\section{Germination experiment under field conditions}

From March to August 2007, i.e. during the whole season, we conducted a seed germination experiment under field conditions in a single patch $(2.0 \times 1.5 \mathrm{~m})$ of a common garden in Viti (eastern part of Kosovo). The patch was covered with a layer of sterilized soil to a depth of $0.3 \mathrm{~m}$. We divided the patch into 30 plots $(30 \times 30 \mathrm{~cm})$, and in each plot we sowed 200 seeds of one species at a depth of 2 $\mathrm{cm}$. Ten randomly chosen plots were used for each species, with five plots for each of the two sub-regions. During sowing, each plot was encased with a cardboard sheet to guarantee a strict separation of the sown seeds. We did not irrigate the experimental site, except for the last two weeks in August due to drought at high temperatures. Seeds were counted and removed once a week. To relate the data on seed germination to the season's soil temperature and precipitation regime, we recorded the soil temperature at the experimental site, using $\mathrm{HOBO}$ data loggers at a soil depth of $5 \mathrm{~cm}$ and used precipitation data from the meteorological station at Ferizaj, located about $20 \mathrm{~km}$ away from Viti. The soil temperature was measured every six hours.

\section{Data analysis and statistics}

We conducted t-tests to see if the length and the width of the seeds used in this study differ between the two subregions of Kosovo.

For each Petri dish in the growth camber experiment we calculated the percentage germination rate reached at the end of the six-week experiment. We performed separate general linear models (GLM) for all three species to test for the effects of region and temperature on germination rate. Differences between temperatures were subsequently tested by Tukey post-hoc tests. Prior to the analysis, data were $\log$-transformed to improve the normality of data distribution. Due to very low germination rates at low temperatures, the results obtained at $3,7,10$ and $5 / 15^{\circ} \mathrm{C}$ were excluded from the analysis.

Moreover, we characterised the germination behaviour based on the following data as described in Olff et al. (1994) and Hölzel and Otte (2004): LOPT, the optimal temperature for germination, was calculated as weighted average of germination rates over all constant temperatures and according to the equation:

$$
\begin{aligned}
& \left(15 \mathrm{P}_{15}+20 \mathrm{P}_{20}+25 \mathrm{P}_{25}+30 \mathrm{P}_{30}+35 \mathrm{P}_{35}\right) / \\
& \left(\mathrm{P}_{15}+\mathrm{P}_{20}+\mathrm{P}_{25}+\mathrm{P}_{30}+\mathrm{P}_{35}\right)
\end{aligned}
$$

where $\mathrm{P}_{15}$ was the percentage germination at $15^{\circ} \mathrm{C}, \mathrm{P}_{20}$ the percentage germination at $20^{\circ} \mathrm{C}$ and so on; LOW, the lowest constant temperature with a germination rate of at least 5\%; $\mathrm{HIGH}$, the highest constant temperature with a germination rate of at least 5\%; AMP, the range in degrees Celsius between HIGH and LOW.

In the field experiment we calculated weekly germination rates (\% of 200 seeds) for all plots and performed a repeated-measure ANOVA on germination rate of each. 'Week' was treated as the within-subject factor, and 'subregion' as between-subject factor for each of the three ANOVA's. Weeks without germination occurrences were excluded from the analyses. Mean values of weekly percentage germination rates were used for visual presentation. All statistical analyses were carried out with STATISTICA 6.0 (StatSoft Inc. 2001).

\section{Results}

\section{Seed size and weight and seed viability}

Seed size of A. retroflexus, E. crus-galli and D. stramonium differed considerably between species, with lowest mean 
Table 1. Seed morphological characteristics of A. retroflexus, E. crus-galli, and D. stramonium, originating from two sub-regions of Kosovo. According to t-tests, seed characteristics of all three species do not differ between the two sub-regions. W = western part of Kosovo, E = eastern part of Kosovo, TKW = thousand-kernel weight.

\begin{tabular}{lcccc}
\hline & Sub-region & $\begin{array}{c}\text { Mean seed length (mm) } \\
\text { and SD }\end{array}$ & $\begin{array}{c}\text { Mean seed width (mm) } \\
\text { and SD }\end{array}$ & TKW (mg) \\
\hline Amaranthus retroflexus & W & 25 & 25 & 461 \\
Echinochloa crus-galli & E & $2.2 \pm 0.1$ & $1.9 \pm 0.1$ & 495 \\
& W & $5.3 \pm 0.1$ & $3.2 \pm 0.1$ & 2291 \\
Datura stramonium & E & $5.4 \pm 0.1$ & $3.2 \pm 0.1$ & 2217 \\
& W & $6.7 \pm 0.1$ & $5.4 \pm 0.1$ & 7461 \\
\hline
\end{tabular}

seed length, width and TKW in $A$. retroflexus and highest values in $D$. stramonium (Table 1). Mean seed length and width did not significantly differ between the two subregions (Table 1). The TKW of $A$. retroflexus was slightly higher in sub-region E, whereas the TKW of E. crus-galli and $D$. stramonium was slightly higher in sub-region W. According to the tetrazolium tests, more than $90 \%$ of the seeds from each pooled seed sample were viable.

\section{Seed germination experiment in climate chambers}

Differences in germination rate due to temperature were significant for all three species and provenances (Table 2, Fig. 2). The significant interaction of temperature and sub-region indicates differences in temperature-dependency between sub-regions, with generally higher germination rates for seeds originating from the western part of the country. Moreover, mean germination rate differed significantly between provenances for some of the tested temperatures. The germination rates were very low for temperatures below $15^{\circ} \mathrm{C}$ and for $5 / 15^{\circ} \mathrm{C}$ (not shown).

In general, germination rates reached at the end of the six-week period were remarkably different between the three species, with highest rates for $A$. retroflexus originating from the western part of Kosovo (around 60\%), and lowest for E. crus-galli from the eastern part (around 10\%). Germination rates of E. crus-galli were much lower than those of the other two species. Amaranthus retroflexus and $D$. stramonium reached comparatively high germination rates at 25,30 and $35^{\circ} \mathrm{C}$, with highest rates at $35^{\circ} \mathrm{C}(A$. retroflexus) or $25^{\circ} \mathrm{C}$ (D. stramonium). However, $45 \%$ of the $D$. stramonium seeds originating from the western part of Kosovo also germinated at $15^{\circ} \mathrm{C}$.

For all three species, the optimal temperature for germination (LOPT) and the lowest constant temperature with a germination rate of at least 5\% (LOW) were lower for seeds originating from the western part of Kosovo than for those from the eastern part (Table 3). Because the highest constant temperature with a germination rate of at least $5 \%(\mathrm{HIGH})$ was $35^{\circ} \mathrm{C}$ for both, the range in degrees Celsius between HIGH and LOW (AMP) was thus higher for seeds originating from the western part.

Table 2. Results of GLMs on the effect of region (SR) and temperature (T) on the seed germination rates of A. retroflexus, E. crus-galli, and $D$. stramonium (for details cf. Fig. 2). $\mathrm{DF}=$ degrees of freedom, $\mathrm{MS}=$ mean squares, $\mathrm{F}=\mathrm{F}$-statistics, $\mathrm{p}=\mathrm{p}$-level.

\begin{tabular}{lcccccccccc}
\hline & \multicolumn{4}{c}{ Amaranthus retroflexus } & \multicolumn{3}{c}{ Echinochloa crus-galli } & \multicolumn{3}{c}{ Datura stramonium } \\
& $\mathrm{DF}$ & $\mathrm{MS}$ & $\mathrm{F}$ & $\mathrm{p}$ & $\mathrm{MS}$ & $\mathrm{F}$ & $\mathrm{p}$ & $\mathrm{MS}$ & $\mathrm{F}$ & $\mathrm{p}$ \\
\hline Intercept & 1 & 311.9 & 3096.8 & $<0.001$ & 161.9 & 1182.1 & $<0.001$ & 214.5 & 1106.0 & $<0.001$ \\
$\mathrm{SR}$ & 1 & 13.9 & 138.5 & $<0.001$ & 0.9 & 6.90 & $<0.05$ & 6.3 & 32.3 & $<0.001$ \\
$\mathrm{~T}$ & 4 & 19.6 & 194.5 & $<0.001$ & 1.0 & 6.9 & $<0.001$ & 11.3 & 58.1 & $<0.001$ \\
$\mathrm{SR} \times \mathrm{T}$ & 4 & 1.3 & 12.4 & $<0.001$ & 0.9 & 6.8 & $<0.001$ & 3.4 & 17.3 & $<0.001$ \\
Error & 40 & 0.10 & & & 0.1 & & & 0.2 & & \\
\hline
\end{tabular}




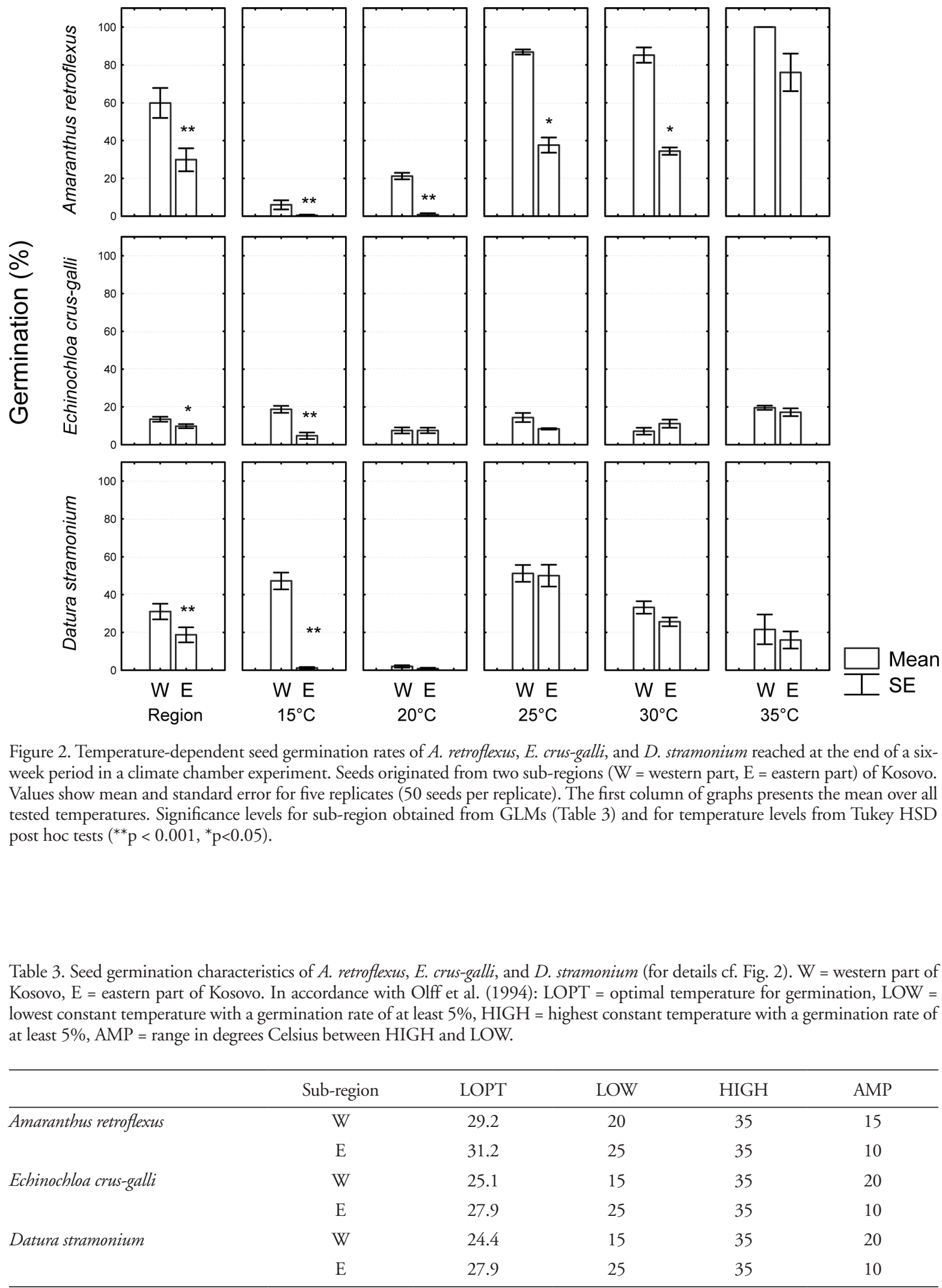




\section{Seed germination under field conditions}

In the field experiment, germination started in May, when the soil temperature had reached $18^{\circ} \mathrm{C}$ and the soil was wet due to rainfall (Fig. 3). Within a few days, an average of $13 \%$ of the five replicates of $A$. retroflexus originating from the western part of Kosovo, and $20 \%$ of the seeds from the eastern part germinated. A second peak of germination (5\%) was recorded in the beginning of June, several days after precipitation. At the same time, the first seeds of $E$. crus-galli and D. stramonium germinated and reached rates from $6 \%$ (D. stramonium, western part) to $15 \%$ (E. crusgalli, eastern part). From mid-June to mid-August hardly any germination took place. This period was characterised by a lack of precipitation and high soil temperatures. Right after this typical summer drought, additionally stimulated by some irrigation, a third but small peak of seed germination (germination rates up to $2 \%$ ) was recorded in the second half of August. At the end of the 25-week experiment, between $8.9 \%$ (D. stramonium, western part) and 39.0\% (E. crus-galli, eastern part) of the seeds were germinated (Table 4).

According to the repeated-measure ANOVA's, the germination rates of all three species differed significantly ( $\mathrm{p}$ $<0.001$ ) between time, but not between the sub-regions. Only the germination rates over time of $D$. stramonium were different between the two sub-regions, as indicated by the significant interaction term in the respective ANOVA.

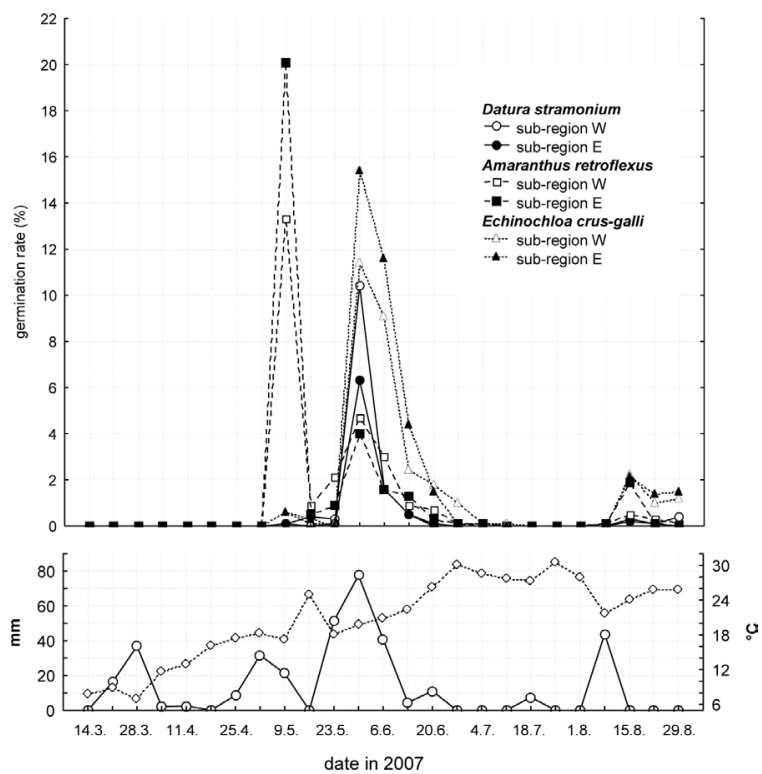

Figure 3. Mean seed germination rates of $A$. retroflexus, E. crusgalli, and $D$. stramonium, originating from two sub-regions of Kosovo, in a germination experiment under field conditions. W = western part of Kosovo, E = eastern part of Kosovo.

\section{Discussion}

Both experiments revealed some differences in germination rate of $A$. retroflexus, E. crus-galli and D. stramonium from different provenances within Kosovo (western part vs eastern part), and thus, gave some support to the hypothesis tested in this study. In the growth chamber experiment, germination rates of all three species differed between provenances as did the experiment under field conditions for germination rate of D. stramonium. The within-region differentiation of the germination behaviour of our species may reflect ecological adaptations to differences in climate and/or land use between sub-regions. However, in this study, we compared pooled seed samples and did not investigate discrete populations. Therefore, further research on the germination behaviour should be undertaken to quantify the degree of adaptation at the population level. In addition, potential driving forces of adaptation processes (e.g. promotion of herbicide-resistant varieties that differ in temperature-dependent germination behaviour; cf. Otte 1996) need to be addressed in detail.

Our results indicate that, for all three species, seeds from the western part of Kosovo may germinate over a broader temperature range than those originating from the eastern part. Considering the longer vegetation period in the western part of Kosovo, a higher plasticity in germination behaviour there might promote a stronger weed infestation. With respect to $D$. stramonium, this result is in accordance with Mehmeti et al. (2009). In this study, D. stramonium was found to be an indicator species (sensu Dufrêne and Legendre 1997), reaching higher abundances and frequencies in the western part of Kosovo.

To counteract the agronomic and ecological problems caused by $A$. retroflexus, E. crus-galli and D. stramonium in Kosovo, changes in weed management are urgently needed. Based on our results and on published reports, we suggest decreasing the proportion of summer crops (including maize) and vegetables in crop rotations. This suggestion is based on the fact that all three species germinate mostly in spring and establish dense populations on (nearly) open soils. However, these weeds are less problematic for winter crops. Because seed germination rates from western Kosovo were higher, weed control is especially important in this part of the country. Also, as seeds from the western part of Kosovo require lower temperatures for germination, weed control must start earlier here (higher temperatures in early spring) and needs to be continued over a longer period of time (higher precipitation during summer). An early application of weed control may be especially important to reduce the abundance of $D$. stramonium in western Kosovo, where seeds start germination at around $15^{\circ} \mathrm{C}$.

Acknowledgements - This study was partially funded by the German Academic Exchange Service (DAAD) and the Univ. of Prishtina. We would like to thank for financial assistance. We also thank Lutz Eckstein and Dietmar Simmering, who helped with 
Table 4. Seed germination rates of A. retroflexus, E. crus-galli and D. stramonium, originating from two sub-regions of Kosovo, in two germination experiments (for details, see Fig. 2 and 3). Cumulative means $(\mathrm{n}=5)$ at the end of the experiments are presented. For the climate chamber experiment, calculation of means refers to the temperature with highest germination rates (cf. Fig. 2: A. retroflexus and E. crus-galli: $35^{\circ} \mathrm{C} ;$ D. stramonium: $25^{\circ} \mathrm{C}$ ).

\begin{tabular}{lccc}
\hline Experiment & & Under field conditions & In climate chambers \\
& Sub-region & Mean germination rate (\%) and SD \\
\hline Amaranthus retroflexus & $\mathrm{W}$ & $26.7 \pm 9.6$ & $100.0 \pm 0.0$ \\
Echinochloa crus-galli & $\mathrm{E}$ & $31.0 \pm 6.9$ & $76.0 \pm 22.2$ \\
& $\mathrm{~W}$ & $31.1 \pm 8.6$ & $19.6 \pm 2.6$ \\
Datura stramonium & $\mathrm{E}$ & $39.0 \pm 3.9$ & $17.2 \pm 4.6$ \\
& $\mathrm{~W}$ & $14.2 \pm 6.1$ & $51.2 \pm 9.9$ \\
\hline
\end{tabular}

statistical analyses and linguistic revision. Moreover, we thank Ahmet Gashi, Agim Mehmeti, Imri Demelezi, Christiane LenzKuhl and Jupp Scholz vom Hofe, who helped in seed collection and preparation and supported the climate chamber experiment, and Ismail Gagica, who prepared Fig. 1.

\section{References}

Barrett, S. C. H. and Wilson, B. F. 1983. Colonizing ability in the Echinochloa crus-galli complex (barnyard grass). II. Seed biology. - Can. J. Bot. 61: 556-562.

Baskin, J. M. and Baskin, C. C. 1977. Role of temperature in the germination ecology of three summer annual weeds. Oecologia 30: 377-382.

Benvenuti, S. et al. 1994. Effects of shade on reproduction and some morphological characteristics of Abutilon theophrasti Medicus, Datura stramonium L. and Sorghum halepense L. Pers. - Weed Res. 34: 283-288.

Bosnic, A. C. and Swanton, C. J. 1997. Influence of barnyardgrass (Echinochloa crus-galli) time of emergence and density on corn (Zea mays). - Weed Sci. 45: 276-282.

Brod, G. 1968. Untersuchungen zur Biologie und Ökologie der Hühner-Hirse Echinochloa crus-galli L. Beauv. - Weed Res. 8: 115-127.

Bürki, H.-M. et al. 1997. Biological control of pigweeds (Amaranthus retroflexus L., A. powellii S. Watson and $A$. bouchonii Thell.) with phytophagous insects, fungal pathogens and crop management. - Integr. Pest Manage. Rev. 2: 51-59.

Cavero, J. et al. 1999. Competition between maize and Datura stramonium in an irrigated field under semi-arid conditions. - Weed Res. 39: 225-240.

Cristaudo, A. et al. 2007. Effects of after-harvest period and environmental factors on seed dormancy of Amaranthus species. - Weed Res. 47: 327-334.

Dufrêne, M. and Legendre, P. 1997. Species assemblages and indicator species: the need for a flexible asymmetrical approach. - Ecol. Monogr. 67: 345-366.

GBIF, Global Biodiversity Information Facility 2009. - < http:// www.gbif.org. 4 Sep 2009>.

Ghorbani, R. et al. 1999. Effects of environmental factors on germination and emergence of Amaranthus retroflexus. - Weed Sci. 47: 505-510.
Glauninger, J. 1984. Untersuchungen über atrazinresistente und -empfindliche Biotypen von Hühnerhirse (Echinochloa crusgalli [L.] P. B.). - Bodenkultur 35: 257-269.

Guo, P. and Al-Khatib, K. 2003. Temperature effects on germination and growth of redroot pigweed (Amaranthus retroflexus), Palmer amaranth (A. palmeri), and common waterhemp $(A$. rudis). - Weed Sci. 51: 869-875.

Hamasha, H. R. and Hensen, I. 2009. Seed germination of four Jordanian Stipa spp: differences in temperature regimes and seed provenances. - Plant Spec. Biol. 24: 127-132.

Honek, A. et al. 1999. Annual cycles of germinability and differences between primary and secondary dormancy in buried seeds of Echinochloa crus-galli. - Weed Res 39: 69-79.

Hölzel, N. and Otte, A. 2004. Ecological significance of seed germination characteristics in flood-meadow species. - Flora 199: $12-24$.

Janjić, V. et al. 2003. Izučavanje fenomena rezistentnosti Amaranthus retroflexus L. prema atrazinu primenom metode fluorescencije listova. - Acta Agric. Serb. 8: 63-72.

Keller, M. and Kollmann, J. 1999. Effects of seed provenance on germination of herbs for agricultural compensation sites. Agric. Ecosyst. Environ. 72: 87-99.

Knežević, S. Ž. et al. 1995. Comparison of empirical models depicting density of Amaranthus retroflexus L. and relative leaf area as predictors of yield loss in maize (Zea mays L.). - Weed Res. 35: 207-214.

Korsmo, E. 1930. Unkräuter im Ackerbau der Neuzeit. - Springer.

Kovačević, A. et al. 2004. Biološka produkcija tatule (Datura stramonium L.), štira (Amaranthus retroflexus (L.) MILL.) i pomoćnice (Solanum nigrum L.) u uslovima primene herbicida u usevu kukuruza. - Acta Herbol. 13: 185-192.

Kozlowski, T. T. 1972. Seed biology. Vol. 2. - Academic Press.

Malan, C. et al. 1982. Control of problem weeds of maize on the Transvaal Highveld (South Africa). II. Datura stramonium L. - Weed Res. 22: 101-104.

Martinkova, Z. and Honek, A. 1995. Termination of dormancy in caryopses of barnyard grass, Echinochloa crus-galli. - Ochr. Rostl. 31: 11-17.

Martinkova, Z. et al. 2006. Seed age and storage conditions influence germination of barnyardgrass (Echinochloa crusgalli). - Weed Sci. 54: 298-304. 
Maun, M. A. and Barrett, S. C. H. 1986. The biology of Canadian weeds, 77: Echinochloa crus-galli (L.) Beauv. - Can. J. Plant Sci. 66: 739-759.

Mehmeti, A. et al. 2008. Ackernutzung und aktuelle Ackervegetation im Kosovo. - Naturschutz Biol. Vielfalt 60: 61-66.

Mehmeti, A. et al. 2009. Plant species richness and composition in arable land of Kosovo. - Landsc. Online 11: 1-29.

Norris, R. F. et al. 2001. Spatial arrangement, density, and competition between barnyard grass and tomato: II. Barnyard grass growth and seed production. - Weed Sci. 49: 69-76.

Nussbaum, E. S. et al. 1985. The effects of temperature and rainfall on emergence and growth of eight weeds. - Weed Sci. 33: $165-170$.

Olff, H. et al. 1994. Germination strategies during grassland succession. - J. Ecol. 82: 69-77.

Oljaća, S. et al. 2006. Jimson weed (Datura stramonium L.) interference in maize. - Maydica 52: 329-333.

Omami, E. N. et al. 1999. Changes in germinability, dormancy and viability of Amaranthus retroflexus as affected by depth and duration of burial. - Weed Res. 39: 345-354.

Otte, A. 1996. Populationsbiologische Parameter zur Kennzeichnung von Ackerwildkräutern. - J. Plant Dis. Prot. Spec. Iss. 15: 45-60.

Rahn, E. M. et al. 1968. Life history studies as related to weed control in the northeast. 5. Barnyard grass. - Agric. Exp. State Univ. Delaw. Bull. 368: 1-46.

Reisman-Berman, O. et al. 1989. Short soaking in water inhibits germination of Datura ferox L. and D. stramonium L. seeds. - Weed Res. 29: 357-363.

Reisman-Berman, O. et al. 1991. Dormancy patterns in buried seeds of Datura ferox and D. stramonium. - Can. J. Bot. 69: 173-179.

Saavedra, M. et al. 1989. Weed flora in the middle valley of the Guadalquivir, Spain. - Weed Res. 29: 167-179.

Sellers, B. A. et al. 2003. Comparative growth of six Amaranthus species in Missouri. - Weed Sci. 51: 329-333.

Simončič, A. and Leskošek, G. 2005. Evaluation of various mechanical measures on weed control efficacy. - Bodenkultur 56: 71-82.
Siriwardana, G. D. and Zimdhal, R. L. 1984. Competition between barnyardgrass (Echinochloa crus-galli) and redroot pigweed (Amaranthus retroflexus). - Weed Sci. 32: 218-222.

Solymosi, P. and Kostyal, S. 1985. Mapping of atrazine resistance for Amaranthus retroflexus L. in Hungary. - Weed Res. 25: 411-414.

Stanković, R. et al.1996. Prilog proučavanju efikasnosti herbicida derivata sulfoniluree. -Zbornik radova. Peti Kongres o korovima. - Banja Koviljača, pp. 518-523.

Statistical Office of Kosovo, 2008a. Series 4. Population statistics. Demographic changes of the Kosovo population 1948-2006. - Statistical Office of Kosovo, Prishtina.

Statistical Office of Kosovo, 2008b. Series 2. Agriculture and environment statistics. Agricultural household survey 2006. - Statistical Office of Kosovo, Prishtina.

Statistical Office of Kosovo, 2009. Series 2: Agriculture and Environment Statistics. Agricultural household survey 2007. Statistical Office of Kosovo, Prishtina.

StatSoft Inc. 2001. STATISTICA for Windows. - < http://www. statsoft.com>.

Steckel, L. E. et al. 2004. Temperature effects on germination of nine Amaranthus species. - Weed Sci. 52: 217-221.

Thompson, K. et al. 1997. The soil seed banks of northwest Europe: methodology, density and longevity. - Cambridge Univ. Press.

Uremis, I. and Uygur, F. N. 2005. Seed viability of some weed species after 7 years of burial in the Cukurova region of Turkey. - Asian J. Plant Sci. 4: 1-5.

Vengris, J. et al. 1966. Growth and development of barnyard grass in Massachusetts. - Weeds 14: 299-301.

Vrbničanin, S. et al. 2004. Adventivne i invazivne korovske vrste na području Srbije. - Acta Herbol. 13: 1-12.

Vrbničanin, S. et al. 2006. Reproductive capacity of Jimson weed (Datura stramonium L.), redroot pigweed (Amaranthus retroflexus L.) and black nightshade (Solanum nigrum L.) under different herbicide regimes in maize. - Res. J. Agric. Biol. Sci. 2: 332-335.

Williams, M. M. et al. 1995. The fitness cost of triazine resistance in Jimson weed (Datura stramonium L.). - Am. Midl. Nat. 133: $131-137$. 